\title{
Functionalization of the pyridazin-3(2H)-one ring via palladium-catalysed aminocarbonylation
}

\author{
Attila Takács ${ }^{\mathrm{a}}$, Andrea Czompa ${ }^{\mathrm{b}}$, Gábor Krajsovszky ${ }^{\mathrm{b}}$, Péter Mátyus ${ }^{\mathrm{b}}$, László Kollár ${ }^{\mathrm{a}, *}$ \\ ${ }^{a}$ Department of Inorganic Chemistry, University of Pécs and János Szentágothai Science Center, H-7624 Pécs, PO Box 266, Hungary \\ ${ }^{\mathrm{b}}$ Department of Organic Chemistry, Semmelweis University, Högyes E. u. 7., H-1092 Budapest, Hungary
}

\section{A R T I C L E I N F O}

Article history:

Received 1 April 2012

Received in revised form 15 June 2012

Accepted 10 July 2012

Available online 17 July 2012

\section{Keywords:}

Aminocarbonylation

Carbon monoxide

Palladium

Pyridazin-3(2H)-one

Amino acid

\begin{abstract}
A B S T R A C T
5-Iodo- and 4,5-dibromo-2-methylpyridazin-3(2H)-ones were aminocarbonylated in the presence of various amines including amino acid methyl esters in a palladium-catalysed reaction. The iodo derivative afforded the corresponding amides with complete conversion and high isolated yields. The dibromo derivative has shown unexpectedly high reactivity in this reaction, resulting in 4,5-dicarboxamides using primary amines as N-nucleophiles. Monoaminocarbonylation has not been observed, i.e., neither 4-bromo-5-carboxamide nor 4-carboxamido-5-bromo derivatives have been formed. However, the use of secondary amines such as piperidine and morpholine resulted in the formations of mixtures of aminosubstituted bromopyridazinones. That is, no carbon monoxide insertion took place in these cases. Some mechanistic details of the formation of aminocarbonylation and amination products are also discussed.
\end{abstract}

(C) 2012 Elsevier Ltd. All rights reserved.

\section{Introduction}

Pyridazin-3(2H)-ones and their fused ring derivatives have gained much attention recently due to their application as synthetic auxiliaries. ${ }^{1}$ Their increasing interest is also due to their pharmacological importance. Pyridazin-3(2H)-one derivatives have been tested as selective histamine receptor inverse antagonists, ${ }^{2}$ phosphodiesterase inhibitors (PDE3, PDE4), ${ }^{3,4}$ agonists for formyl peptide receptors ${ }^{5}$ and some compounds show excellent $\alpha$-adrenoceptor blocking properties, one of which has entered Phase II clinical studies as a potential drug candidate for the treatment of benign prostatic hyperplasia.

Among the wide variety of synthetic reactions the application of organometallic reagents such as Grignard-reagents of different nucleophilicity, 6,7 and especially, that of homogeneous catalysis play an important role in the functionalization of pyridazinones. As recent examples, the application of Suzuki-Miyaura reaction for synthesis of 4(5)-mono and 4,5-diarylated pyridazin-3(2H)-ones ${ }^{8}$ and that of the 4,6-diaryl/heteroarylpyridazinones ${ }^{9}$ and 5,6diarylpyridazinones ${ }^{10}$ should be mentioned. A Suzuki coupling was used as a key reaction in a multistep synthesis of azecine ring systems. ${ }^{11}$ An intramolecular Heck reaction proved to be very efficient for the synthesis of $5 H$-pyridazino[4,5-b]indoles and its benzofurane analogues. ${ }^{12}$

\footnotetext{
* Corresponding author. E-mail address: kollar@ttk.pte.hu (L. Kollár).
}

Recently, a facile synthetic procedure for the synthesis of iodosubstituted pyridazin-3(2H)-ones from the corresponding chloro derivatives was published. ${ }^{13}$ As a part of our continuing interest in the systematic investigation of palladium-catalysed carbonylation reactions, the aminocarbonylation of iodo- and bromopyridazin$3(2 \mathrm{H})$-ones to give the corresponding carboxamides is reported, which was expected to open a direct route to otherwise not easily accessible oxopyridazinecarboxamides.

\section{Results and discussion}

2.1. Aminocarbonylation of 5-iodo-2-methylpyridazin-3(2H)one (1) leading to 5-carboxamido-2-methylpyridazin-3(2H)ones (2)

5-Iodo-2-methylpyridazin-3(2H)-one (1) was reacted with $\mathrm{N}$ nucleophiles such as tert-butylamine (a) and piperidine (b) under atmospheric carbon monoxide pressure in DMF in the presence palladium $(0)$ catalysts generated in situ from palladium(II) acetate catalytic precursor (Scheme 1 ). It is worth noting that although the reduction of $\mathrm{Pd}(\mathrm{II})$ precursors to $\mathrm{Pd}(0)$ species has been proved in the presence of various phosphines while they have been oxidised to $\mathrm{P}(\mathrm{V})$ derivatives (monophosphine oxides or diphosphine oxide/ hemioxide), ${ }^{14-16}$ the mechanism of reduction under reductive conditions (carbon monoxide, primary or secondary amines) is still not known. 


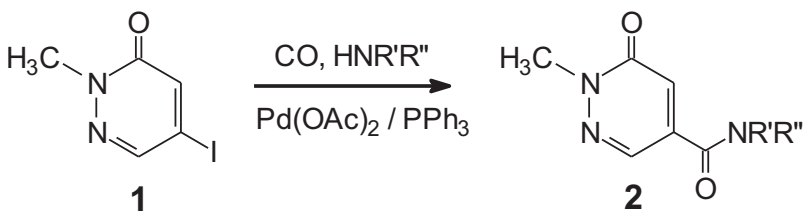

$$
\begin{array}{lll} 
& \mathrm{R}^{\prime} & \mathrm{R} " \\
\text { a } & \mathrm{H} & t \mathrm{Bu} \\
\text { b } & -\left(\mathrm{CH}_{2}\right)_{5-}^{-} \\
\text {d } & \mathrm{H} & \mathrm{Ph} \\
\text { e } & \mathrm{H} & \mathrm{CH}\left(\mathrm{CH}_{3}\right) \mathrm{COOCH}_{3} \\
\text { f } & \mathrm{H} & \mathrm{CH}_{2} \mathrm{COOCH}_{3} \\
\text { g } & -\mathrm{CH}\left(\mathrm{COOCH}_{3}\right)\left(\mathrm{CH}_{2}\right)_{3-}^{-}
\end{array}
$$

Scheme 1. The synthesis of 5-carboxamido-2-methylpyridazin-3(2H)-one derivatives via the aminocarbonylation reaction.

Highly selective reactions were observed with all primary and secondary amines, such as tert-butylamine (a), piperidine (b), aniline (d), methyl alaninate (e), methyl glycinate (f) and methyl prolinate $(\mathbf{g})$ resulting in the exclusive formation of the corresponding 5-carboxamides (2a-2g). Accordingly, all compounds were isolated in good yields even without further optimization. Practically complete conversion was achieved both under atmospheric and high (40 bar) carbon monoxide pressures (Table 1, entries 1-4). Unlike the aminocarbonylation of iodoarenes and aryl triflates no double carbon monoxide insertion was observed. ${ }^{17}$ That is, the corresponding 2-oxocarboxamides were even not detected. Mild reaction conditions could be used efficiently in the presence of the less nucleophilic amine (d) (entry 5) and amino acid esters (e-g) (entries 6-8) as N-nucleophiles. This sharp difference between the aminocarbonylation of conventional iodoarenes (e.g., iodobenzene) and iodopyridazinones can be explained by the different electronic structure of the Pd-acyl intermediates. That is, the 2-methylpyridazin-3(2H)-one-5-oyl-palladium(II) intermediate (the corresponding Pd-acyl complex) is reluctant to form the acylcarbamoyl complex, that might lead to the double carbonylated derivatives via reductive elimination.

Table 1

Palladium-catalysed aminocarbonylation of $\mathbf{1}^{\mathrm{a}, \mathrm{b}}$

\begin{tabular}{llcl}
\hline Entry & Amine & $p(\mathrm{CO})$ [bar] & Isolated yield $^{\mathrm{c}}$ (amide) [\%] \\
\hline 1 & $\mathbf{a}$ & 1 & $79(\mathbf{2 a})$ \\
2 & $\mathbf{a}$ & 40 & $67(\mathbf{2 a})$ \\
3 & $\mathbf{b}$ & 1 & $70(\mathbf{2 b})$ \\
4 & $\mathbf{b}$ & 40 & $68(\mathbf{2 b})$ \\
5 & $\mathbf{d}$ & 1 & $54(\mathbf{2 d})$ \\
6 & $\mathbf{e}$ & 1 & $66(\mathbf{2 e})$ \\
7 & $\mathbf{f}$ & 1 & $54(\mathbf{2 f})$ \\
8 & $\mathbf{g}$ & 1 & $66(\mathbf{2 g})$ \\
\hline
\end{tabular}

a Reaction conditions: $\mathrm{Pd}(\mathrm{OAc})_{2},(0.025 \mathrm{mmol}), \mathrm{PPh}_{3}(0.05 \mathrm{mmol})$, substrate (1) $(1.0 \mathrm{mmol}), \mathbf{a}(3.0 \mathrm{mmol})$ (or b $(1.5 \mathrm{mmol}), \mathbf{d}(2.0 \mathrm{mmol}), \mathbf{e}-\mathbf{g}(1.1 \mathrm{mmol}))$, triethylamine $(0.5 \mathrm{~mL}), \mathrm{DMF}(10 \mathrm{~mL})$; temperature: $50^{\circ} \mathrm{C}$, reaction time: $24 \mathrm{~h}$.

b Practically complete conversion (>99\%) determined by GC-MS was obtained in all cases.

c Based on the amount of the substrate (1) used.

\subsection{Aminocarbonylation of 4,5-dibromo-2-methylpyridazin- $3(2 \mathrm{H})$-one (3) leading to 4,5-dicarboxamido-2- methylpyridazin-3(2H)-ones (4)}

4,5-Dibromo-2-methylpyridazin-3(2H)-one (3) was reacted with primary amines such as tert-butylamine (a), aniline (d), methyl alaninate (e), methyl glycinate (f), as well as secondary amines such as piperidine (b) and morpholine (c) in the next series of aminocarbonylation reactions (Scheme 2, Table 2). The two types of N-nucleophiles led to completely different products.

The use of $\mathbf{a}, \mathbf{e}$ and $\mathbf{f}$ resulted in the formation of dicarboxamides 4a, 4e and 4f, respectively (Table 2, entries 1, 2, 6, 9-11). Practically complete conversion was obtained with a in $24 \mathrm{~h}$, but longer reaction times were needed to obtain the target compounds in acceptable yields using amino acid esters (e and $\mathbf{f}$ ) as N-nucleophiles. The diamides were isolated in moderate to high yields in all cases. Diamides were obtained even in those cases where the amine nucleophiles were used in sub-stoichiometric amounts (entries 7 and 8).

It is worth noting that the pyridazine-based dibromo substrate (3) has shown much higher reactivity towards palladium-catalysed aminocarbonylation than bromoarenes or bromoalkenes ever tested in the same reaction under similar conditions. ${ }^{17,18}$ The conversion and isolated yield data closely match those obtained with the corresponding iodo derivatives (iodoaromatics, iodoalkenes) or triflates (aryl triflates, enol-triflates). (However, the application of the less basic primary amine (d) did not lead to the corresponding diamides or amines in isolable yields, that is, a mixture of some minor products was obtained.). The high reactivity of 4,5dibromopyridazinone we observed in an aminocarbonylation reaction might be related to its $\pi$-deficient nature and the increased electrophilicity of both its 4 - and 5-positions.

Contrary to primary amines, direct amination instead of aminocarbonylation was observed with secondary amines (b and $\mathbf{c}$ ). Monoamination took place with both amines either in position-4 or -5 and accordingly, both $\mathbf{5}$ and $\mathbf{5}^{\prime}$ were isolated from the same reaction mixture (Table 2, entries $3-5$ ). The position of the amino and bromo substituents on the pyridazinone ring, resulted in regioisomers of closely related structure, was determined by detailed 2D NMR measurements. Surprisingly, the 'second' bromo substituent was not substituted. The corresponding amide or diamide derivatives (4) could not be detected either by GC-MS or NMR, i.e., no carbon monoxide insertion leading to the expected carboxamides took place. Comparing the reactivity of the iodopyridazinone and bromopyridazinone, it should be mentioned that the latter substrate is much sensitive towards the basicity of the $\mathrm{N}$ nucleophile. Consequently, the most basic secondary amines (b,c) react directly with the palladium(II)-aryl species (see below) without the insertion of carbon monoxide. The application of the Nnucleophile with lowest basicity (d) resulted in the formation of no compounds in an isolable amount.

The formation of the dicarboxamides and amines from the dibromopyridazino derivative (3) can be interpreted by a simplified mechanism depicted in Scheme 3.

The substrate $(\mathbf{3})$ reacts with the coordinatively unsaturated palladium $(0)$ complex, formed in situ, resulting in aryl-palladium intermediate (A) via oxidative addition. It is followed by carbon monoxide coordination leading to carbonyl complex (B) and the insertion of carbon monoxide into the palladium(II)-aryl bond. The formed palladium-acyl derivatives $(\mathbf{C})$ are intercepted by the primary amines resulting in the formation of a monobromomonocarboxamido intermediate. The abstraction of $\mathrm{HBr}$ with triethylamine provides the 'starting' palladium(0) complex via reductive elimination. In the 'second' cycle (Cycle-II), the oxidative addition of the monobromo intermediate provides the palladium-aryl complex $\left(\mathbf{A}^{\prime}\right)$, which reacts further via the palladium terminal carbonyl $\left(\mathbf{B}^{\prime}\right)$ and palladium-acyl $\left(\mathbf{C}^{\prime}\right)$ intermediate to dicarboxamide $\mathbf{4}$ as described for the analogous 'first' cycle (Cycle-I, A-B-C).

However, in case of the secondary amines, the palladium-aryl intermediates (the oxidative addition products $\mathbf{A}$ and $\mathbf{A}^{\prime \prime}$ ) might react directly with the $\mathrm{N}$-nucleophiles resulting in the bromoamino products (5 and $\mathbf{5}^{\prime}$, respectively). That is, unlike the above two 'carbonylation cycles' (Cycle-I and Cycle-II) the carbon 


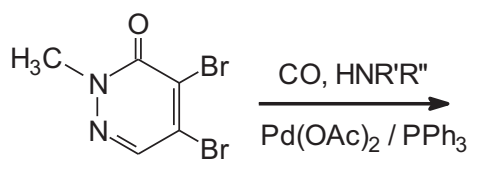

3<smiles>[R7]NC(=O)c1cnn(C)c(=O)c1C(=O)N[R7]</smiles>

4<smiles>[R7]Nc1cnn(C)c(=O)c1Br</smiles>
5<smiles>[R7]Nc1c(Br)cnn(C)c1=O</smiles>

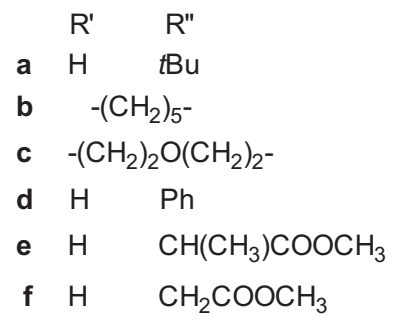

Scheme 2. The synthesis of 4,5-dicarboxamido-2-methylpyridazin-3(2H)-one derivatives via an aminocarbonylation reaction.

Table 2

Palladium-catalysed aminocarbonylation of $\mathbf{3}^{\mathrm{a}}$

\begin{tabular}{lllccll}
\hline Entry & Amine & $\begin{array}{l}\text { 3/amine } \\
\text { molar ratio }\end{array}$ & $\begin{array}{l}p(\mathrm{CO}) \\
{[\mathrm{bar}]}\end{array}$ & $\begin{array}{l}\text { R. time } \\
{[\mathrm{h}]}\end{array}$ & $\begin{array}{l}\text { Conversion } \\
{[\%]}\end{array}$ & $\begin{array}{l}\text { Isolated } \\
\text { yield }^{\mathrm{d}}[\%]\end{array}$ \\
\hline 1 & $\mathbf{a}$ & $1: 6$ & 1 & 24 & $>98(\mathbf{4 a})$ & $73(\mathbf{4 a})$ \\
2 & $\mathbf{a}$ & $1: 6$ & 40 & 24 & $>98(\mathbf{4 a})$ & $62(\mathbf{4 a})$ \\
3 & $\mathbf{b}$ & $1: 3$ & 1 & 24 & $>98\left(\mathbf{5 b}, \mathbf{5}^{\prime} \mathbf{b}\right)$ & $52(\mathbf{5 b}) ;$ \\
& & & & & & $17\left(\mathbf{5}^{\prime} \mathbf{b}\right)$ \\
4 & $\mathbf{b}$ & $1: 3$ & 40 & 24 & $>98\left(\mathbf{5 b}, \mathbf{5}^{\prime} \mathbf{b}\right)$ & $50(\mathbf{5 b}) ;$ \\
& & & & & & $19\left(\mathbf{5}^{\prime} \mathbf{b}\right)$ \\
5 & $\mathbf{c}$ & $1: 3$ & 1 & 24 & $>98\left(\mathbf{5 c}, \mathbf{5}^{\prime} \mathbf{c}\right)$ & $68(\mathbf{5 c})$ \\
& & & & & & $17\left(\mathbf{5}^{\prime} \mathbf{c}\right)$ \\
7 & $\mathbf{e}$ & $1: 2.2$ & 1 & 168 & $88(\mathbf{4 e})$ & $45(\mathbf{4 e})$ \\
8 & $\mathbf{e}$ & $1: 1.1$ & 40 & 24 & $50(\mathbf{4 e})$ & n.d. \\
9 & $\mathbf{e}$ & $1: 1.1$ & 40 & 69 & $52(\mathbf{4 e})$ & $15(\mathbf{4 e})$ \\
10 & $\mathbf{e}$ & $1: 2.2$ & 40 & 24 & $90(\mathbf{4 e})$ & $65(\mathbf{4 e})$ \\
11 & $\mathbf{f}$ & $1: 2.2$ & 40 & 24 & $83(\mathbf{4 f})$ & n.d. \\
\hline
\end{tabular}

a Reaction conditions: $\mathrm{Pd}(\mathrm{OAc})_{2}(0.025 \mathrm{mmol}), \mathrm{PPh}_{3}(0.05 \mathrm{mmol})$, substrate (3) $(1.0 \mathrm{mmol})$, triethylamine $(0.5 \mathrm{~mL}), \mathrm{DMF}(10 \mathrm{~mL})$; temperature: $50{ }^{\circ} \mathrm{C}$.

$\mathrm{b}$ The products (including minor products) are indicated in brackets.

c Determined by GC and GC-MS.

d Based on the amount of the substrate (3) used.

monoxide insertion is not operative. $\mathrm{A}$ base $\left(\mathrm{NEt}_{3}\right)$ is also needed in these 'amination catalytic cycles' (Cycle-III and Cycle-IV) as a hydrogen bromide acceptor in order to re-form the coordinatively unsaturated palladium $(0)$ species. It has to be added that the amino products, including the two regioisomers ( $\mathbf{5}$ and $\mathbf{5}^{\prime}$ ) could also be formed by a direct nucleophilic substitution reaction without the formation of Pd-intermediates. ${ }^{19}$

\section{Conclusions}

It has been shown that both iodo- and bromopyridazinones can be efficiently transformed into the corresponding carboxamides via a palladium-catalysed aminocarbonylation. Especially the unexpectedly high reactivity of the dibromopyridazinone derivative compared to conventional bromoarene test substrates should be emphasised. This method provides simple and efficient way to obtain new pyridazinecarboxamides. It is worth noting that under same conditions, the dibromopyridazinone substrate reacts directly with secondary amines resulting in the formation of the bromoamino isomers instead of carboxamides, which perhaps might also be utilized for amination of such substrates, as a mild alternative to classical nucleophilic substitution.
The appropriate choice of the reaction conditions enabled the isolation of all above-mentioned compounds including the minor products.

\section{Experimental}

\subsection{General procedures}

${ }^{1} \mathrm{H}$ and ${ }^{13} \mathrm{C}$ NMR spectra were recorded in $\mathrm{CDCl}_{3}$ on a Varian Inova 400 spectrometer at $400.13 \mathrm{MHz}$ and $100.62 \mathrm{MHz}$, respectively. Chemical shifts $\delta$ are reported in parts per million relative to $\mathrm{CHCl}_{3}$ (7.26 and $77.00 \mathrm{ppm}$ for ${ }^{1} \mathrm{H}$ and ${ }^{13} \mathrm{C}$, respectively). Elemental analyses were measured on an 1108 Carlo Erba apparatus. Samples of the catalytic reactions were analysed with a Hewlett Packard 5830A gas chromatograph fitted with a capillary column coated with OV-1. The FTIR spectra were taken in $\mathrm{KBr}$ pellets using an IMPACT 400 spectrometer (Nicolet) applying a DTGS detector in the region of $400-4000 \mathrm{~cm}^{-1}$, the resolution was $4 \mathrm{~cm}^{-1}$. The amount of the samples was ca. $0.5 \mathrm{mg}$.

The substrates $\mathbf{1}^{12}$ and $3^{20,21}$ were synthesised as described previously. Amines (a-d) and amino acid esters (e, f, g) were purchased from Sigma-Aldrich. Silica gel 60 (Merck, $0.063-0.200 \mathrm{~mm}$ ) was used for column chromatography.

\subsection{Aminocarbonylation of 5-iodo-2-methylpyridazin-3(2H)- one (1) under atmospheric carbon monoxide pressure}

In a typical experiment $\mathrm{Pd}(\mathrm{OAc})_{2}(5.6 \mathrm{mg}, 0.025 \mathrm{mmol}), \mathrm{PPh}_{3}$ (13.1 $\mathrm{mg}, \quad 0.050 \mathrm{mmol}$ ), 5-iodo-2-methylpyridazin-3(2H)-one (236 mg, $1.0 \mathrm{mmol}), 3 \mathrm{mmol}$ of a (or the amount of amine given in Table 1$)$ and triethylamine $(0.5 \mathrm{~mL})$ were dissolved in DMF $(10 \mathrm{~mL})$ under argon in a $100 \mathrm{~mL}$ three-necked flask equipped with a gas inlet and a reflux condenser with a balloon at the top. The atmosphere was changed to carbon monoxide. The reaction was conducted for the given reaction time upon stirring at $50{ }^{\circ} \mathrm{C}$ and analysed by GC-MS. The mixture was then concentrated and evaporated to dryness. The residue was dissolved in chloroform $(20 \mathrm{~mL})$ and washed with water $(2 \times 20 \mathrm{~mL})$. The organic phase was dried over $\mathrm{Na}_{2} \mathrm{SO}_{4}$ and evaporated to a solid material or to a waxy residue. All compounds were subjected to column chromatography using the solvent mixture indicated for the $R_{f}$ values in Section 4.6. 


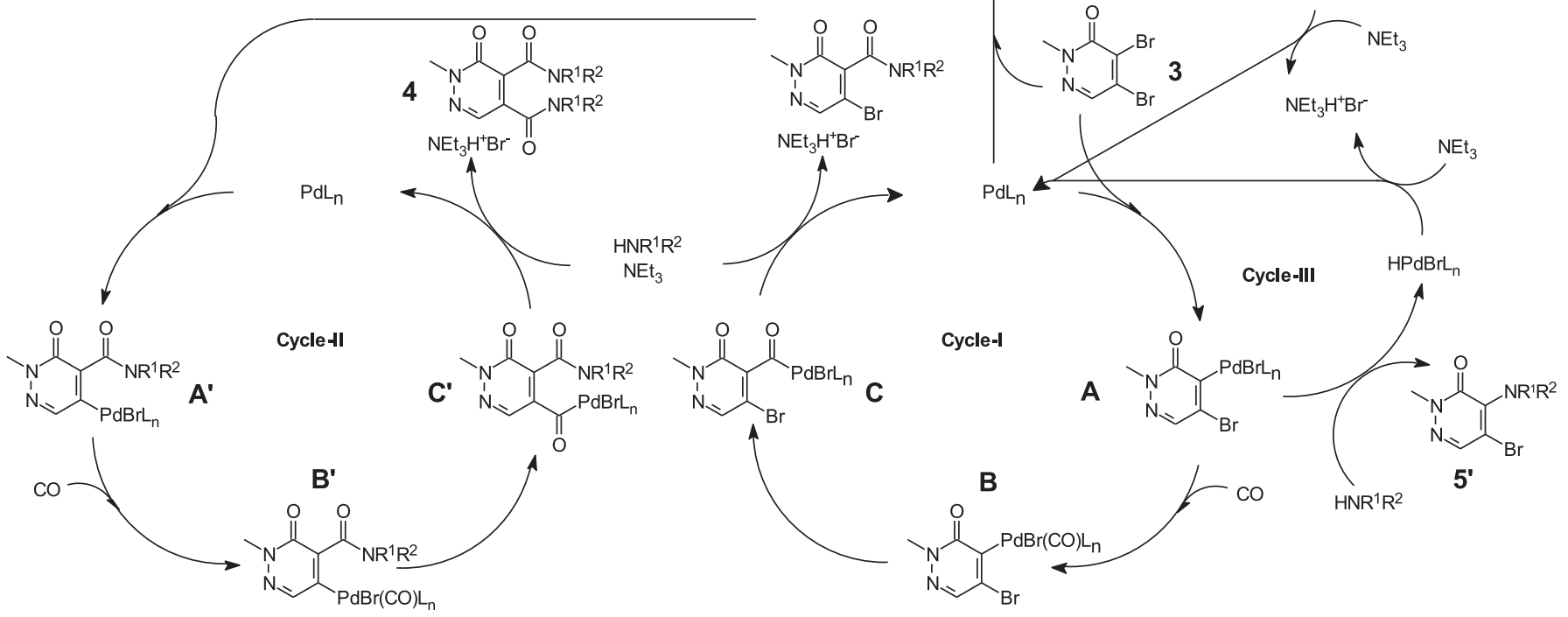

Scheme 3. The simplified mechanism for the palladium-catalysed transformations of $\mathbf{3}$.

\subsection{Aminocarbonylation of 5-iodo-2-methylpyridazin-3(2H)- one (1) under high carbon monoxide pressure}

The above amounts of catalyst, substrate and amines were dissolved in DMF (10 mL) under argon in a $100 \mathrm{~mL}$ autoclave. The atmosphere was changed to carbon monoxide and the autoclave was pressurized to 40 bar with carbon monoxide. The reaction was conducted for the given reaction time upon stirring at $50{ }^{\circ} \mathrm{C}$ and analysed by GC-MS. The work-up procedure was identical to that described in Section 4.2.

\subsection{Aminocarbonylation of 4,5-dibromo-2-methylpyridazin- $3(2 \mathrm{H})$-one (3) under atmospheric carbon monoxide pressure}

In a typical experiment $\mathrm{Pd}(\mathrm{OAc})_{2}(5.6 \mathrm{mg}, 0.025 \mathrm{mmol}), \mathrm{PPh}_{3}$ (13.1 mg, $0.05 \mathrm{mmol}$ ), 4,5-dibromo-2-methylpyridazin-3(2H)-one (268 mg, $1.0 \mathrm{mmol}$ ), tert-butylamine (a) $(6 \mathrm{mmol}$ ) (or the amount of amine given in Table 2) and triethylamine $(0.5 \mathrm{~mL})$ were dissolved in DMF $(10 \mathrm{~mL})$ under argon in a $100 \mathrm{~mL}$ three-necked flask equipped with a gas inlet, reflux condenser with a balloon at the top. The atmosphere was changed to carbon monoxide. The reaction was conducted for the given reaction time upon stirring at $50{ }^{\circ} \mathrm{C}$ and analysed by GC-MS. The work-up procedure was identical to that described in Section 4.2.

\subsection{Aminocarbonylation of 4,5-dibromo-2-methylpyridazin- $3(2 \mathrm{H})$-one (3) under high carbon monoxide pressure}

The above amounts of catalyst, substrate and amines were dissolved in DMF (10 mL) under argon in a $100 \mathrm{~mL}$ autoclave. The atmosphere was changed to carbon monoxide and the autoclave was pressurized to 40 bar with carbon monoxide. The reaction was conducted for the given reaction time upon stirring at $50{ }^{\circ} \mathrm{C}$ and analysed by GC-MS. The work-up procedure was identical with those described in Section 4.2.

\subsection{Characterization of the products}

4.6.1. 5-(N-tert-Butylcarboxamido)-2-methylpyridazin-3(2H)-one (2a). Yield: $166 \mathrm{mg}$ (79\%); white solid, $\mathrm{mp} 152-153^{\circ} \mathrm{C}$. Found: C, 57.20; $\mathrm{H}, 7.41 ; \mathrm{N}, 19.89 . \mathrm{C}_{10} \mathrm{H}_{15} \mathrm{~N}_{3} \mathrm{O}_{2}$ requires $\mathrm{C}, 57.40 ; \mathrm{H}, 7.23 ; \mathrm{N}$, $20.08 \% . R_{f}\left(50 \% \mathrm{EtOH} / \mathrm{CHCl}_{3}\right) 0.34 ; \delta_{\mathrm{H}}\left(400 \mathrm{MHz}, \mathrm{CDCl}_{3}\right) 8.13(1 \mathrm{H}, \mathrm{d}$, $1.5 \mathrm{~Hz}, \mathrm{Ar}-\mathrm{H}), 7.25(1 \mathrm{H}, \mathrm{d}, 1.5 \mathrm{~Hz}, \mathrm{Ar}-\mathrm{H}), 6.1(1 \mathrm{H}, \mathrm{br} \mathrm{s}, \mathrm{NH}), 3.77(3 \mathrm{H}$, $\left.\mathrm{s}, \mathrm{N}-\mathrm{CH}_{3}\right), 1.45\left(9 \mathrm{H}, \mathrm{s}, \mathrm{C}\left(\mathrm{CH}_{3}\right)_{3}\right) ; \delta_{\mathrm{C}}\left(100.6 \mathrm{MHz}, \mathrm{CDCl}_{3}\right)$ 162.0, 160.3, 138.2, 135.1, 125.4, 52.4, 40.2, 28.5; IR ( $\left.\mathrm{KBr}, \nu\left(\mathrm{cm}^{-1}\right)\right)$ : $3300(\mathrm{v} \mathrm{br}$, $\mathrm{NH}), 1669\left(\mathrm{CH}_{3} \mathrm{NCO}\right), 1653$ (CON). MS m/z (rel int.): $209\left(43, \mathrm{M}^{+}\right)$, 194 (55), 154 (57), 137 (100), 109 (25), 57 (16).

4.6.2. 5-(N,N-Pentan-1,5-diylcarboxamido)-2-methylpyridazin3(2H)-one (2b). Yield: $155 \mathrm{mg}$ (70\%); beige solid, mp $119-120^{\circ} \mathrm{C}$. Found: $\mathrm{C}, 59.60 ; \mathrm{H}, 7.01 ; \mathrm{N}, 18.80 . \mathrm{C}_{11} \mathrm{H}_{15} \mathrm{~N}_{3} \mathrm{O}_{2}$ requires $\mathrm{C}, 59.71 ; \mathrm{H}$, 6.83; N, $18.99 \% . R_{f}\left(50 \% \mathrm{EtOAc} / \mathrm{CHCl}_{3}\right) 0.27 ; \delta_{\mathrm{H}}\left(400 \mathrm{MHz}, \mathrm{CDCl}_{3}\right)$ $7.72(1 \mathrm{H}, \mathrm{d}, 1.5 \mathrm{~Hz}, \mathrm{Ar}-\mathrm{H}), 6.79(1 \mathrm{H}, \mathrm{d}, 1.5 \mathrm{~Hz}, \mathrm{Ar}-\mathrm{H}), 3.77(3 \mathrm{H}, \mathrm{s}$, $\left.\mathrm{N}-\mathrm{CH}_{3}\right), 3.68-3.63\left(2 \mathrm{H}, \mathrm{m}, \mathrm{N}-\mathrm{CH}_{2}\right), 3.37-3.33\left(2 \mathrm{H}, \mathrm{m}, \mathrm{N}-\mathrm{CH}_{2}\right), 1.67$ $\left(4 \mathrm{H}\right.$, br s, $\left.2 \mathrm{CH}_{2}\right), 1.57-1.53\left(2 \mathrm{H}, \mathrm{m}, \mathrm{CH}_{2}\right) ; \delta_{\mathrm{C}}\left(100.6 \mathrm{MHz}, \mathrm{CDCl}_{3}\right)$ 163.5, 159.8, 139.2, 134.2, 125.5, 48.3, 42.9, 40.2, 26.5, 25.3, 24.1; IR $\left(\mathrm{KBr} \nu\left(\mathrm{cm}^{-1}\right)\right): 1667$ ( $\left.\mathrm{CH}_{3} \mathrm{NCO}\right), 1630$ (CON); MS m/z (rel int.): 221 (83, $\left.\mathrm{M}^{+}\right), 193$ (7), 178 (27), 150 (100), 137 (31), 109 (46), 84 (49).

4.6.3. 5-(N-Phenylcarboxamido)-2-methylpyridazin-3(2H)-one (2d). Yield: $124 \mathrm{mg}$ (54\%), off-white solid, $\mathrm{mp} 218-219{ }^{\circ} \mathrm{C}$. Found: $\mathrm{C}, 62.66 ; \mathrm{H}, 4.97 ; \mathrm{N}, 18.22 . \mathrm{C}_{12} \mathrm{H}_{11} \mathrm{~N}_{3} \mathrm{O}_{2}$ requires $\mathrm{C}, 62.84 ; \mathrm{H}, 4.84 ; \mathrm{N}$, $18.33 \% . R_{f}\left(50 \% \mathrm{EtOAc} \mathrm{CHCl}_{3}\right) 0.38 ; \delta_{\mathrm{H}}\left(400 \mathrm{MHz}, \mathrm{CDCl}_{3}\right) 9.50(1 \mathrm{H}, \mathrm{br}$ s, NH), $8.36(1 \mathrm{H}, \mathrm{s}, \mathrm{Ar}-\mathrm{H}), 7.86(2 \mathrm{H}, \mathrm{d}, 7.4 \mathrm{~Hz}, \mathrm{Ph}$ (ortho)), $7.66(1 \mathrm{H}, \mathrm{s}$, $\mathrm{Ar}-\mathrm{H}), 7.41(2 \mathrm{H}, \mathrm{t}, 7.4 \mathrm{~Hz}, \mathrm{Ph}($ meta $)), 7.20(1 \mathrm{H}, \mathrm{t}, 7.4 \mathrm{~Hz}, \mathrm{Ph}($ para $))$, $3.86\left(3 \mathrm{H}, \mathrm{s}, \mathrm{N}-\mathrm{CH}_{3}\right) ; \delta_{\mathrm{C}}\left(100.6 \mathrm{MHz}, \mathrm{CDCl}_{3}\right) 160.9,160.7,138.0,137.6$, 135.8, 129.0, 125.7, 125.2, 120.4, 40.5; IR $\left(\mathrm{KBr} \nu\left(\mathrm{cm}^{-1}\right)\right): 3336(\mathrm{v}$, $\mathrm{NH}), 1681.5\left(\mathrm{CH}_{3} \mathrm{NCO}\right), 1649(\mathrm{CON}) ; \mathrm{MS} m / z$ (rel int.): $229\left(100, \mathrm{M}^{+}\right)$, 212 (5), 200 (11), 171 (5), 137 (9), 120 (5), 109 (18), 92 (5), 77 (13).

4.6.4. 5-(N-(1-(Methoxycarbonyl)ethyl)carboxamido)-2methylpyridazin-3(2H)-one (2e). Yield: $158 \mathrm{mg}$ (66\%), beige solid, 
mp 138-139 ${ }^{\circ} \mathrm{C}$. Found: $\mathrm{C}, 50.03 ; \mathrm{H}, 5.52 ; \mathrm{N}, 17.69 . \mathrm{C}_{10} \mathrm{H}_{13} \mathrm{~N}_{3} \mathrm{O}_{4}$ requires $\mathrm{C}, 50.21 ; \mathrm{H}, 5.48 ; \mathrm{N}, 17.56 \% . R_{f}\left(50 \% \mathrm{EtOAc} / \mathrm{CHCl}_{3}\right) 0.36 ; \delta_{\mathrm{H}}$ $\left(400 \mathrm{MHz}, \mathrm{CDCl}_{3}\right) 8.19(1 \mathrm{H}, \mathrm{d}, 2.0 \mathrm{~Hz}, \mathrm{Ar}-\mathrm{H}), 7.68(1 \mathrm{H}, \mathrm{d}, 6.9 \mathrm{~Hz}$, $\mathrm{NH}), 7.42(1 \mathrm{H}, \mathrm{d}, 2.0 \mathrm{~Hz}, \mathrm{Ar}-\mathrm{H}), 4.73(1 \mathrm{H}, \mathrm{dq}, 7.3 \mathrm{~Hz}, 6.9 \mathrm{~Hz}, \mathrm{~N}-\mathrm{CH})$, $3.81\left(3 \mathrm{H}, \mathrm{s}, \mathrm{O}-\mathrm{CH}_{3}\right), 3.79\left(3 \mathrm{H}, \mathrm{s}, \mathrm{N}-\mathrm{CH}_{3}\right), 1.56(3 \mathrm{H}, \mathrm{d}, 7.3 \mathrm{~Hz}$, $\left.\mathrm{CH}-\mathrm{CH}_{3}\right) ; \delta_{\mathrm{C}}\left(100.6 \mathrm{MHz}, \mathrm{CDCl}_{3}\right) 172.8,162.4,160.3,136.6,134.9$, 126.3, 52.6, 48.7, 40.3, 17.7; IR (KBr $\left.\nu\left(\mathrm{cm}^{-1}\right)\right): 3299$ (v br, NH), 1747 (COO), $1677.5\left(\mathrm{CH}_{3} \mathrm{NCO}\right), 1655$ (CON); MS $m / z$ (rel int.): 239 (23, $\mathrm{M}^{+}$), 208 (2), 180 (85), 137 (100), 124 (6), 109 (19), 66 (8).

4.6.5. 5-(N-(Methoxycarbonylmethyl)carboxamido)-2methylpyridazin-3(2H)-one (2f). Yield: $121 \mathrm{mg}$ (54\%), brown solid, mp $172-173{ }^{\circ} \mathrm{C}$. Found: $\mathrm{C}, 47.78 ; \mathrm{H}, 4.80 ; \mathrm{N}, 18.51 . \mathrm{C}_{9} \mathrm{H}_{11} \mathrm{~N}_{3} \mathrm{O}_{4}$ requires C, 48.00; $\mathrm{H}, 4.92 ; \mathrm{N}, 18.66 \% . R_{f}\left(50 \% \mathrm{EtOAc} / \mathrm{CHCl}_{3}\right) 0.19 ; \delta_{\mathrm{H}}$ $\left(400 \mathrm{MHz}, \mathrm{CDCl}_{3}\right) 8.19(1 \mathrm{H}, \mathrm{d}, 1.9 \mathrm{~Hz}, \mathrm{Ar}-\mathrm{H}), 7.78-7.63(1 \mathrm{H}, \mathrm{m}, \mathrm{NH})$, $7.34(1 \mathrm{H}, \mathrm{d}, 1.9 \mathrm{~Hz}, \mathrm{Ar}-\mathrm{H}), 4.21\left(2 \mathrm{H}, \mathrm{d}, 5.1 \mathrm{~Hz}, \mathrm{~N}-\mathrm{CH}_{2}\right), 3.81(3 \mathrm{H}, \mathrm{s}$, $\left.O-\mathrm{CH}_{3}\right), 3.8\left(3 \mathrm{H}, \mathrm{s}, \mathrm{N}-\mathrm{CH}_{3}\right) ; \delta_{\mathrm{C}}\left(100.6 \mathrm{MHz}, \mathrm{CDCl}_{3}\right)$ 169.7, 163.0, 160.3, 136.6, 134.7, 126.4, 52.6, 41.6, 40.4; IR ( $\left.\mathrm{KBr} \nu\left(\mathrm{cm}^{-1}\right)\right): 3348$ (v br, $\mathrm{NH}$ ), 1748 (COO), 1653 (vs, $\mathrm{CH}_{3} \mathrm{NCO}+\mathrm{CON}$ ); MS m/z (rel int.): 225 $\left(100, \mathrm{M}^{+}\right), 194$ (3), 166 (33), 137 (95), 109 (41), 88 (15), 66 (15).

4.6.6. 5-(N,N-(1-Methoxycarbonyl-butan-1,4-diyl)-carboxamido)-2methylpyridazin-3(2H)-one $(\mathbf{2 g})$, (ca. 5:1 mixture of two $C(O) N$ rotamers). Yield: $176 \mathrm{mg}$ (66\%), orange viscous material. Found: $\mathrm{C}$, $54.21 ; \mathrm{H}, 5.81 ; \mathrm{N}, 15.68 . \mathrm{C}_{12} \mathrm{H}_{15} \mathrm{~N}_{3} \mathrm{O}_{4}$ requires $\mathrm{C}, 54.33 ; \mathrm{H}, 5.70 ; \mathrm{N}$, 15.84\%. $R_{f}\left(50 \% \mathrm{EtOAc} / \mathrm{CHCl}_{3}\right) 0.19 ; \delta_{\mathrm{H}}\left(400 \mathrm{MHz}, \mathrm{CDCl}_{3}\right) 7.81 / 7.68$ (major/minor), (1H, d, $1.9 \mathrm{~Hz}, \mathrm{Ar}-\mathrm{H}), 6.92 / 6.70$ (major/minor) $(1 \mathrm{H}$, d, $1.9 \mathrm{~Hz}, \mathrm{Ar}-\mathrm{H}), 4.57-4.54 / 4.35-4.32$ (major/minor) $(1 \mathrm{H}, \mathrm{m}$, $\mathrm{N}-\mathrm{CH}$ ), 3.73 (3H, s, $\left.N-\mathrm{CH}_{3}\right), 3.70 / 3.59$ (major/minor) $(3 \mathrm{H}, \mathrm{s}$, $\left.O-\mathrm{CH}_{3}\right), \quad 3.61-3.57\left(1 \mathrm{H}, \quad \mathrm{m}, \quad N-\mathrm{CH}_{\mathrm{a}} \mathrm{H}_{\mathrm{b}}\right), 3.47-3.43(1 \mathrm{H}, \mathrm{m}$, $\left.N-\mathrm{CH}_{\mathrm{a}} \mathrm{H}_{\mathrm{b}}\right), 2.06-1.80\left(4 \mathrm{H}, \mathrm{m}, 2 \mathrm{CH}_{2}\right) ; \delta_{\mathrm{C}}\left(100.6 \mathrm{MHz}, \mathrm{CDCl}_{3}\right) 171.7 /$ 171.6 (minor/major), 164.1/163.4 (minor/major), 159.7/159.6 (major/minor), 139.6/138.6 (minor/major), 134.2, 126.3/125.1 (major/ minor), 60.7/59.1 (minor/major), 52.8/52.4 (minor/major), 49.3/ 46.5 (major/minor), 40.2, 31.2/29.0 (minor/major), 25.0/22.4 (major/minor); IR ( $\left.\mathrm{KBr} \nu\left(\mathrm{cm}^{-1}\right)\right)$ : 1747 (COO), 1669 ( $\left.\mathrm{CH}_{3} \mathrm{NCO}\right), 1655$ (CON); MS $m / z$ (rel int.): 265 (13, $\mathrm{M}^{+}$), 234 (2), 222 (9), 206 (100), 150 (4), 137 (79), 109 (16), 66 (5).

4.6.7. 4,5-Bis(N-tert-butylcarboxamido)-2-methylpyridazin-3(2H)one (4a). Yield: $226 \mathrm{mg}$ (73\%), white solid, $\mathrm{mp} 194-195^{\circ} \mathrm{C}$. Found: C, 58.49; $\mathrm{H}, 7.94 ; \mathrm{N}, 18.03 . \mathrm{C}_{15} \mathrm{H}_{24} \mathrm{~N}_{4} \mathrm{O}_{3}$ requires $\mathrm{C}, 58.42 ; \mathrm{H}, 7.84 ; \mathrm{N}$, $18.17 \% . R_{f}\left(50 \% \mathrm{EtOAc} / \mathrm{CHCl}_{3}\right) 0.50 ; \delta_{\mathrm{H}}\left(400 \mathrm{MHz}, \mathrm{CDCl}_{3}\right) 7.93(1 \mathrm{H}$, br s, $\mathrm{NH}), 7.89(1 \mathrm{H}, \mathrm{s}, \mathrm{Ar}-\mathrm{H}), 6.72(1 \mathrm{H}, \mathrm{br} \mathrm{s}, \mathrm{NH}), 3.78\left(3 \mathrm{H}, \mathrm{s}, \mathrm{N}-\mathrm{CH}_{3}\right) ; 1.41$ $\left(18 \mathrm{H}, \mathrm{s}, \mathrm{C}\left(\mathrm{CH}_{3}\right)_{3}\right) ; \delta_{\mathrm{C}}\left(100.6 \mathrm{MHz}, \mathrm{CDCl}_{3}\right) 163.3,161.2,159.3,138.6$, 136.4, 128.2, 52.3, 52.1, 40.8, 28.4, 28.3; $\operatorname{IR}\left(\operatorname{KBr} \nu\left(\mathrm{cm}^{-1}\right)\right)$ : $3272(\mathrm{v} \mathrm{br}$, $\mathrm{NH}), 1673\left(\mathrm{CH}_{3} \mathrm{NCO}\right), 1643$ (CON); MS $m / z$ (rel int.): $308\left(8, \mathrm{M}^{+}\right), 293$ (3), 251 (11), 236 (22), 209 (7), 180 (100), 162 (8), 58 (30).

4.6.8. 4,5-Bis(N-(1-(methoxycarbonyl)ethyl)carboxamido)-2methylpyridazin-3(2H)-one (4e). Yield: $230 \mathrm{mg}$ (65\%), beige solid, mp 105-106 ${ }^{\circ} \mathrm{C}$. Found: $\mathrm{C}, 48.70 ; \mathrm{H}, 5.31 ; \mathrm{N}, 15.02 . \mathrm{C}_{15} \mathrm{H}_{20} \mathrm{~N}_{4} \mathrm{O}_{7}$ requires $\mathrm{C}, 48.91 ; \mathrm{H}, 5.47 ; \mathrm{N}, 15.21 \% . R_{f}$ (EtOAc) $0.55 ; \delta_{\mathrm{H}}(400 \mathrm{MHz}$, $\left.\mathrm{CDCl}_{3}\right) 9.76(1 \mathrm{H}, \mathrm{d}, 6.9 \mathrm{~Hz}, \mathrm{NH}), 7.86(1 \mathrm{H}, \mathrm{s}, \mathrm{Ar}-\mathrm{H}), 6.75(1 \mathrm{H}, \mathrm{d}$, $6.9 \mathrm{~Hz}, \mathrm{NH}), 4.74(1 \mathrm{H}, \mathrm{dq}, 7.2 \mathrm{~Hz}, \mathrm{~N}-\mathrm{CH}), 4.65(1 \mathrm{H}, \mathrm{dq}, 7.2 \mathrm{~Hz}, 6.9 \mathrm{~Hz}$, $N-\mathrm{CH}), 3.85\left(3 \mathrm{H}, \mathrm{s}, \mathrm{O}-\mathrm{CH}_{3}\right), 3.75\left(3 \mathrm{H}, \mathrm{s}, N-\mathrm{CH}_{3}\right), 3.73(3 \mathrm{H}, \mathrm{s}$, $\left.N-\mathrm{CH}_{3}\right), 1.5\left(3 \mathrm{H}, \mathrm{d}, 7.2 \mathrm{~Hz}, \mathrm{CH}-\mathrm{CH}_{3}\right), 1.46\left(3 \mathrm{H}, \mathrm{d}, 7.2 \mathrm{~Hz}, \mathrm{CH}-\mathrm{CH}_{3}\right) ; \delta_{\mathrm{C}}$ $\left(100.6 \mathrm{MHz}, \mathrm{CDCl}_{3}\right)$ 172.9, 172.6, 164.4, 160.5, 160.0, 140.8, 135.9, 124.6, 52.6, 52.5, 48.6, 48.5, 41.3, 18.1, 17.8; IR $\left(\mathrm{KBr} \nu\left(\mathrm{cm}^{-1}\right)\right): 3299$ (v br, NH), 1747 (COO), 1685 ( $\left.\mathrm{CH}_{3} \mathrm{NCO}\right), 1651$ (CON); MS m/z (rel int.): $368\left(1, \mathrm{M}^{+}\right), 309$ (34), $266(100), 206(81), 179(10), 162$ (5), 136 (10), 110 (8), 93 (5), 59(5).

4.6.9. 4,5-Bis(N-(methoxycarbonylmethyl)carboxamido)-2methylpyridazin-3(2H)-one (4f). Yield: $179 \mathrm{mg}$ (52\%), beige solid, mp $142-143{ }^{\circ} \mathrm{C}$. Found: C, 45.77; $\mathrm{H}, 4.57 ; \mathrm{N}, 16.29 . \mathrm{C}_{13} \mathrm{H}_{16} \mathrm{~N}_{4} \mathrm{O}_{7}$ requires C, 45.88; $\mathrm{H}, 4.74 ; \mathrm{N}, 16.46 \% . R_{f}\left(\right.$ EtOAc) $0.29 ; \delta_{\mathrm{H}}(400 \mathrm{MHz}$, $\left.\mathrm{CDCl}_{3}\right) 9.86(1 \mathrm{H}, \mathrm{s}, \mathrm{NH}), 7.9(1 \mathrm{H}, \mathrm{s}, \mathrm{Ar}-\mathrm{H}), 6.86(1 \mathrm{H}, \mathrm{s}, \mathrm{NH}), 4.23(2 \mathrm{H}$, d, $\left.5.2 \mathrm{~Hz}, \mathrm{~N}-\mathrm{CH}_{2}\right), 4.16\left(2 \mathrm{H}, \mathrm{d}, 5.2 \mathrm{~Hz}, \mathrm{~N}-\mathrm{CH}_{2}\right), 3.88\left(3 \mathrm{H}, \mathrm{s}, \mathrm{O}-\mathrm{CH}_{3}\right)$, $3.78\left(3 \mathrm{H}, \mathrm{s}, \mathrm{N}-\mathrm{CH}_{3}\right), 3.76\left(3 \mathrm{H}, \mathrm{s}, \mathrm{N}-\mathrm{CH}_{3}\right) ; \delta_{\mathrm{C}}\left(100.6 \mathrm{MHz}, \mathrm{CDCl}_{3}\right)$ 169.7, 169.3, 164.9, 161.3, 159.8, 140.7, 135.6, 124.2, 52.4 (double intensity), 41.6, 41.4, 41.3; IR ( $\left.\mathrm{KBr} \nu\left(\mathrm{cm}^{-1}\right)\right)$ : 3324 (v br, NH), 1755 (COO), $1674\left(\mathrm{CH}_{3} \mathrm{NCO}\right), 1670$ (CON); MS $m / z$ (rel int.): $340\left(1.8, \mathrm{M}^{+}\right.$), 309 (1.8), 281 (3.5), 252 (74), 192 (100), 164 (7), 136 (12), 110 (19), 93 (12), 59(17).

4.6.10. 4-Bromo-5-(N,N-pentan-1,5-diylamino)-2-methylpyridazin$3(2 \mathrm{H})$-one (5b). Yield: $142 \mathrm{mg}$ (52\%), yellow viscous material. Found: C, 44.02; $\mathrm{H}, 5.40 ; \mathrm{N}, 15.19 . \mathrm{C}_{10} \mathrm{H}_{14} \mathrm{~N}_{3} \mathrm{OBr}$ requires $\mathrm{C}, 44.13 ; \mathrm{H}$, $5.19 ; \mathrm{N}, 15.44 \% . R_{f}\left(20 \% \mathrm{EtOAc} / \mathrm{CHCl}_{3}\right) 0.62 ; \delta_{\mathrm{H}}\left(400 \mathrm{MHz}, \mathrm{CDCl}_{3}\right) 7.42$ $(1 \mathrm{H}, \mathrm{s}, \mathrm{Ar}-\mathrm{H}), 3.66\left(3 \mathrm{H}, \mathrm{s}, \mathrm{N}-\mathrm{CH}_{3}\right), 3.26-3.21\left(4 \mathrm{H}, \mathrm{m}, 2 \mathrm{~N}-\mathrm{CH}_{2}\right)$, $1.63-1.56\left(6 \mathrm{H}, \mathrm{m}, 3 \mathrm{CH}_{2}\right) ; \delta_{\mathrm{C}}\left(100.6 \mathrm{MHz}, \mathrm{CDCl}_{3}\right) 158.9,151.2,130.8$, 109.2, 50.6, 40.5, 25.8, 23.8; IR ( $\left.\mathrm{KBr} \nu\left(\mathrm{cm}^{-1}\right)\right): 1636\left(\mathrm{CH}_{3} \mathrm{NCO}\right)$; MS $\mathrm{m} / z$ (rel int.): 271/273 (80, $\mathrm{M}^{+}$), 230(11), 192 (100), 164 (9), 146 (13), 124 (11), 84 (9), 55 (16).

4.6.11. 5-Bromo-4-(N,N-pentan-1,5-diylamino)-2-methylpyridazin$3(2 \mathrm{H})$-one $\left(\mathbf{5}^{\prime} \mathbf{b}\right)$. Yield: $52 \mathrm{mg}$ (19\%), yellow viscous material. Found: $\mathrm{C}, 44.22 ; \mathrm{H}, 5.33 ; \mathrm{N}, 15.24 . \mathrm{C}_{10} \mathrm{H}_{14} \mathrm{~N}_{3} \mathrm{OBr}$ requires $\mathrm{C}, 44.13 ; \mathrm{H}$, $5.19 ; \mathrm{N}, 15.44 \% . R_{f}\left(20 \% \mathrm{EtOAc} / \mathrm{CHCl}_{3}\right) 0.86 ; \delta_{\mathrm{H}}\left(400 \mathrm{MHz}, \mathrm{CDCl}_{3}\right) 7.66$ $(1 \mathrm{H}, \mathrm{s}, \mathrm{Ar}-\mathrm{H}), 3.68\left(3 \mathrm{H}, \mathrm{s}, \mathrm{N}-\mathrm{CH}_{3}\right), 3.42-3.35\left(4 \mathrm{H}, \mathrm{m}, \mathrm{N}-\mathrm{CH}_{2}\right)$, $1.75-1.60\left(6 \mathrm{H}, \mathrm{m}, 3 \mathrm{CH}_{2}\right) ; \delta_{\mathrm{C}}\left(100.6 \mathrm{MHz}, \mathrm{CDCl}_{3}\right) 159.2,146.6,140.3$, 110.8, 51.3, 40.0, 26.6, 24.2; $\mathrm{IR}\left(\mathrm{KBr} \nu\left(\mathrm{cm}^{-1}\right)\right): 1636\left(\mathrm{CH}_{3} \mathrm{NCO}\right)$; $\mathrm{MS}$ $m / z$ (rel int.): 271/273 (36, $\mathrm{M}^{+}$), 242/244 (10), 216/218 (14), 192 (41), 162 (10), 109 (28), 84 (100), 52 (21).

4.6.12. 4-Bromo-5-(N,N-3-oxapentan-1,5-diylamino)-2methylpyridazin-3(2H)-one (5c). Yield: $187 \mathrm{mg}$ (68\%), yellow solid, mp $134-135^{\circ} \mathrm{C}$. Found: C, 39.29; H, 4.60; N, 15.08; $\mathrm{C}_{9} \mathrm{H}_{12} \mathrm{~N}_{3} \mathrm{O}_{2} \mathrm{Br}$ requires C, 39.44; $\mathrm{H}, 4.41 ; \mathrm{N}, 15.33 \% . R_{f}\left(30 \% \mathrm{EtOAc} / \mathrm{CHCl}_{3}\right) 0.31 ; \delta_{\mathrm{H}}$ $\left(400 \mathrm{MHz}, \mathrm{CDCl}_{3}\right) 7.41(1 \mathrm{H}, \mathrm{s}, \mathrm{Ar}-\mathrm{H}), 3.75-3.68\left(4 \mathrm{H}, \mathrm{m}, 2 \mathrm{O}-\mathrm{CH}_{2}\right)$, $3.65\left(3 \mathrm{H}, \mathrm{s}, \mathrm{N}-\mathrm{CH}_{3}\right), 3.30-3.23\left(4 \mathrm{H}, \mathrm{m}, 2 \mathrm{~N}-\mathrm{CH}_{2}\right) ; \delta_{\mathrm{C}}(100.6 \mathrm{MHz}$, $\left.\mathrm{CDCl}_{3}\right)$ 158.5, 150.2, 130.1, 110.8, 66.4, 49.4, 40.5; $\mathrm{IR}\left(\mathrm{KBr} \nu\left(\mathrm{cm}^{-1}\right)\right)$ : $1629\left(\mathrm{CH}_{3} \mathrm{NCO}\right)$; MS $m / z$ (rel int.): 273/275 (76, $\left.\mathrm{M}^{+}\right), 215 / 217$ (17), 194 (100), 166 (19), 146 (17), 108 (14), 86 (2), 65 (16).

4.6.13. 5-Bromo-4-(N,N-3-oxapentan-1,5-diylamino)-2-methylpyridazin-3(2H)-one $\left(\mathbf{5}^{\prime} \mathbf{c}\right)$. Yield: $47 \mathrm{mg}(17 \%)$, pale yellow solid, $\mathrm{mp}$ $121-123{ }^{\circ} \mathrm{C}$. Found: $\mathrm{C}, 39.26 ; \mathrm{H}, 4.55 ; \mathrm{N}, 15.19 . \mathrm{C}_{9} \mathrm{H}_{12} \mathrm{~N}_{3} \mathrm{O}_{2} \mathrm{Br}$ requires $\mathrm{C}, 39.44 ; \mathrm{H}, 4.41 ; \mathrm{N}, 15.33 \% . R_{f}\left(30 \% \mathrm{EtOAc} / \mathrm{CHCl}_{3}\right) 0.43 ; \delta_{\mathrm{H}}$ $\left(400 \mathrm{MHz}, \mathrm{CDCl}_{3}\right) 7.68(1 \mathrm{H}, \mathrm{s}, \mathrm{Ar}-\mathrm{H}), 3.82-3.75\left(4 \mathrm{H}, \mathrm{m}, 2 \mathrm{O}-\mathrm{CH}_{2}\right)$, $3.68\left(3 \mathrm{H}, \mathrm{s}, \mathrm{N}-\mathrm{CH}_{3}\right), 3.51-3.44\left(4 \mathrm{H}, \mathrm{m}, 2 \mathrm{~N}-\mathrm{CH}_{2}\right) ; \delta_{\mathrm{C}}(100.6 \mathrm{MHz}$, $\left.\mathrm{CDCl}_{3}\right)$ 158.7, 145.2, 140.0, 111.5, 67.4, 50.1, 40.0; $\mathrm{IR}\left(\mathrm{KBr} \nu\left(\mathrm{cm}^{-1}\right)\right)$ : $1629\left(\mathrm{CH}_{3} \mathrm{NCO}\right) ; \mathrm{MS} m / z$ (rel int.): 273/275 (9, $\left.\mathrm{M}^{+}\right), 255 / 257$ (36), 188/190 (100), 162 (11), 136 (15), 109 (73), 86 (15), 52 (69).

\section{Acknowledgements}

The authors thank the Hungarian Research Fund (CK78553 and K73389) and Developing Competitiveness of Universities in the South Transdanubian Region (SROP-4.2.1.B-10/2/KONV-2010-0002 and SROP-4.2.2./B-16 10/1-2010-0029) for the financial support and Johnson Matthey for the generous gift of palladium(II) acetate.

\section{References and notes}

1. Lee, S.-G.; Kim, J.-J.; Kim, H.-K.; Kweon, D.-H.; Kang, Y.-J.; Cho, S.-D.; Kim, S.-K.; Yoon, Y.-J. Curr. Org. Chem. 2004, 8, 1463-1480.

2. Hudkins, R. L.; Raddatz, R.; Tao, M.; Mathiasen, J. R.; Aimone, L. D.; Becknell, N. C.; Prouty, C. P.; Knutsen, L. J. S.; Yazdanian, M.; Moachon, G.; Ator, M. A.; Mallamo, J. P.; Marino, M. J.; Bacon, E. R.; Williams, M. J. Med. Chem. 2011, 54, $4781-4792$. 
3. Allcock, R. W.; Blakli, H.; Jiang, Z.; Johnston, K. A.; Morgan, K. M.; Rosair, G. M.; Iwase, K.; Kohno, Y.; Adams, D. R. Bioorg. Med. Chem. Lett. 2011, 21, 3307-3312.

4. Hori, M.; Iwama, T.; Asakura, Y.; Kawanishi, M.; Kamon, J.; Hoshino, A.; Takahashi, S.; Takahashi, K.; Nakaike, S.; Tsuruzoe, N. Eur. J. Pharmacol. 2009, 618, 63-69.

5. Cilibrizzi, A.; Quinn, M. T.; Kirpotina, L. N.; Schepetkin, I. A.; Holderness, J.; Ye, R. D.; Rabiet, M.-J.; Biancalani, C.; Cesari, N.; Graziano, A.; Vergelli, C.; Pieretti, S.; Piaz, V. D.; Giovannoni, M. P. J. Med. Chem. 2009, 32, 5044-5057.

6. Verhelst, T.; Maes, J.; Liu, Z. M.; Sergeyev, S.; Maes, B. U. W. J. Org. Chem. 2011, 76, 6670-6677.

7. Ryabtsova, O.; Verhelst, T.; Baeten, M.; Velde, C. M. L. V.; Maes, B. U. W. J. Org. Chem. 2009, 74, 9440-9445.

8. Maes, B.; Tapolcsányi, P.; Meyers, K.; Mátyus, P. Curr. Org. Chem. 2006, 10, 377-417.

9. Clapham, K. M.; Batsanov, A. S.; Greenwood, R. D. R.; Bryce, M. R.; Smith, A. E.; Tarbit, B. J. Org. Chem. 2008, 73, 2176-2181.

10. Coelho, A.; Sotelo, E.; Estevez, I.; Ravina, E. Synthesis 2001, 871-876.

11. Dunkel, P.; Túrós, G.; Bényei, A.; Ludányi, K.; Mátyus, P. Tetrahedron 2010, 66, 2331-2339.
12. Dajka-Halász, B.; Monsieurs, K.; Elias, O.; Károlyházy, L.; Tapolcsányi, P.; Maes, B. U. W.; Riedl, Z.; Hajós, G.; Dommisse, R. A.; Lemiere, G. L. F.; Kosmrlj, J.; Mátyus, P. Tetrahedron 2004, 60, 2283-2291.

13. Károlyházy, L.; Krajsovszky, G.; Farkas, L.; Boros, S.; Csámpai, A.; Mátyus, P. Arkivoc 2011, ii, 18-28.

14. Amatore, C.; Jutand, A.; Khalil, F.; M'Barki, M. A.; Mottier, L. Organometallics 1993, 12, 3168-3178.

15. Amatore, C.; Carre, E.; Jutand, A.; M'Barki, M. A.; Meyer, G. Organometallics $1995,14,5605-5614$

16. Csákai, Z.; Skoda-Földes, R.; Kollár, L. Inorg. Chim. Acta 1999, 286, 93-97.

17. Skoda-Földes, R.; Kollár, L. Curr. Org. Chem. 2002, 6, 1097-1119 and references cited therein.

18. Arcadi, A. Carbonylation of Enolizable Ketones (Enol Triflates) and Iodoalkenes In Modern Carbonylation Methods; Kollár, L., Ed.; Wiley-VCH: Weinheim, 2008, Chapter 9, pp 223-250, and references cited therein.

19. Mátyus, P.; Czakó, K.; Behr, Á; Varga, I.; Podányi, B.; von Arnim, M.; Várkonyi, P. Heterocycles 1993, 36, 785-798.

20. Mowry, D. T. J. Am. Chem. Soc. 1953, 75, 1909-1910.

21. Terai, T.; Azuma, H.; Hattori, R. Japan 1300(67) (Cl. 16 E 463); Chem. Abstr. 1967, $66,65497 z$. 